\title{
Research Article \\ Burnout Syndrome as the Example of Psychological Costs of Work - Empirical Studies among Human-Oriented Professions in Poland
}

\author{
Urszula ZALUSKA, Dorota KWIATKOWSKA-CIOTUCHA \\ And Magdalena SLAZYK-SOBOL
}

\author{
Wroclaw University of Economics and Business, Wroclaw, Poland \\ The University of Wroclaw, Wroclaw, Poland
}

Correspondence should be addressed to: Urszula ZALUSKA; urszula.zaluska@ue.wroc.pl

Received date:8 January 2020; Accepted date:6 july 2020; Published date: 19 August 2020

Academic Editor : Katarzyna Świerszcz

Copyright (C) 2020. Urszula ZALUSKA, Dorota KWIATKOWSKA-CIOTUCHA And Magdalena

SLAZYK-SOBOL Distributed under Creative Commons Attribution 4.0 International CC-BY 4.0

\begin{abstract}
Burnout syndrome is a very well-known psychological process, which has been described and measured in psychological literature for the last 40 years. Nevertheless, this kind of psychological "experience" is still very important for both: researchers and practitioners: trainers, psychologists, coaches, managers - who are trying to support a given professional group with adequate preventive action, based on empirical studies. The purpose of the presented research was firstly to measure the perception and knowledge about the phenomenon of burnout among employers working in direct contact with patients, clients, students, pupils. The authors define burn out using the latest organizational conception by Maslach and Leiter $(2010,2011,2012)$ which explains it as the consequence of lacking fit between professional work (it's environment) and an individual. The authors decided to measure the level of burnout using the LBQ Professional Burnout Questionnaire, which is an adaptation of the Italian Link Burnout Questionnaire. On the other hand, they constructed the original questionnaire designed to assess the probability of the phenomenon among Polish workers. The study was conducted in June and July 2017 as part of the transnational cooperation project (Time2Grow), which aims to develop an effective prevention tool for burnout dedicated to nurses, health care professionals, teachers and academic teachers/ researcher. To analyse achieved results two methods of econometric modelling were used - one of them to identify differences between employees in terms of main predictors of occupational burnout (logistic regression) and the next one was used to estimate the level of experienced burnout symptoms (classification method - two-steps cluster analysis). Presented results suggest that there were important practical conclusions. Every research group presented different burn - out predictors and significantly different level of experienced burn out. It should be underlined, that especially the higher education sector is lacking empirical research concerning wellbeing, organizational stress and burn out consequences. Additionally, there is a deep need to strengthen interpersonal skills and personal resources of researcher and academic teachers working. There are also significant differences between the knowledge and awareness of burn-out syndrome among researched groups.
\end{abstract}

Keywords: professional burnout, predictors of burnout, human-oriented profession, psychological costs of work, econometric modelling.

JEL Classification: C59, M54.

Cite this Article as: Urszula ZALUSKA, Dorota KWIATKOWSKA-CIOTUCHA And Magdalena SLAZYKSOBOL (2020)," Burnout Syndrome as the Example of Psychological Costs of Work - Empirical Studies among Human-Oriented Professions in Poland", IBIMA Business Review, Vol. 2020 (2020), Article ID 430264, DOI: $10.5171 / 2020.430264$ 


\section{Introduction}

The aim of this paper is to make an initial estimation of the perception of the phenomenon of burnout in Poland and to generate a discussion about an issue that is both important and difficult but often overlooked. The article provides insight into some of the research findings that are the result of the activities undertaken in an international research project dedicated to the prevention of burnout. The inspiration to undertake presented empirical research in the field of occupational burnout, with particular emphasis on professional groups such as teachers, academic teachers and healthcare representatives, was the analysis of the literature on the subject and the specific situation of these professional groups in Poland. The authors of the publication have practical experience concerning cooperation with presented professional groups due to the implementation of an innovative $\mathrm{EU}$ project: Time2Grow (a transnational cooperation project POWR.04.03.00-00W300/16, implementation period April 2017 - December 2019, cooperation between Belgium and Finland). It's worth to underline that especially in Poland academic teachers are a professional group generally omitted in empirical research concerning organizational pathologies such as burnout (Lubrańska 2012, Majchrzak, 2011, Świętochowski 2011). However, work in a higher education area may be related to great psychological costs Psychological research indicates that the level of personality traits such as agreeableness and emotional stability can be crucial for further prediction of occurring burnout (Ruggieri, Crescenzo and others, 2018). Other study shows that emotional coping predicted greater levels of burnout among staff working with students with special needs (Brittle, 2020), what underlines the role of interpersonal skills when it comes to work in higher education area. In higher education, such factors as: experiencing role conflict, ambiguity of tasks, pressure to achieve scientific results, lack of greater support from universities are very common on the way of building career paths. A high level of expectations and a complicated and very often unclear procedure determining the promotion process influence the motivation of employees to invest in their professional development. Additionally, academic teachers are working with very specific clients, representing various types of studies, which can generate a lot of challenges as well as professional burdens. Taking into account the burnout process among academic teachers, potential consequences have a negative impact on the quality of research and also influenced creativity of researchers and decrease the level of delivered teaching at universities. Burn out among academic teachers is leading to greater professional disappointment and lowered self-efficacy as well as lowered organizational engagement. Similar to the area of education and health care, relatively low salaries can generate additional frustration for employees. Among Polish teachers, apart from organizational factors (such as the level of salaries, difficult working conditions - overcrowded school classes, a lot of educational changes caused by the political reforms), very stressful factors are: relationships and contacts with students, their parents, guardians and colleagues. Despite the fact that teachers are one of the best described professional group, when it comes to diagnose of occupational burn out process (Cherniss, 1980, Cherniss, 1995, Cieślik, 2012, Gavish, Friedman, 2010), there is still a gap concerning the practical, but empirically verified solutions of effective burnout prevention.

Health care employees have always been associated with emotional overload and high level of stressful situations at work. Predictors of burnout in this professional group are connected with direct contact with patients, their pain, emotions, and their general situation. According to literature (Dyrbye, West, Johnson, Cipriano, Beatty, Peterson and others, 2019), in some research such factors as: demographics, work hours and highest academic degree are independent predictors of burnout 
among nurses. Especially work hours and professional development were related to the risk of burnout among nurses, what seems to be very similar to polish context. It is important to underline that very often the burnout syndrome can be evoked by pathological organizational factors, appearing at workplace, such as organizational culture and climate. For example, the moral distress and bullying can significantly predict the level of burnout in health care professions (Ajoudani, Baghaei, Lotfi, 2019). Primary research carried out as part of the Time2Grow project confirmed that Polish health care employees work in several places at the same time for financial reasons. The low level of salaries causes growing tendency to take up an additional part tome job, what definitely influences private social and family life. Lack of free time, psychophysical overload and generally permanent physical and emotional effort at work are additional factors burning this professional group. The course of building an accurate and useful model (which is to prevent burnout and minimize its effects), the authors have carried out a primary research which addressed the problem of how the phenomenon of burnout is perceived and how its symptoms are experienced among the representatives of three groups: healthcare professionals, education professionals and - what seems to be particularly innovative - higher education professionals (for the purpose of this article, the aforementioned professional groups will also be referred to as "sectors"). To meet the objective of the research, two research questions must have been asked:

1. Do the employees in Poland perceive (are aware of) the phenomenon of burnout (and to what extent)?

2. Are there any differences in the perception of burnout and its symptoms among the representatives of the three professional groups that, as the subject literature suggests, might be especially vulnerable to the syndrome?
The article presents the results of using two methods of econometric modelling to identify differences between employees in terms of main predictors of occupational burnout (logistic regression) and to evaluate the level of experienced burnout symptoms (classification method - twosteps cluster analysis). It should be pinpoint that selected professional group were considered as those where the risk of occupational burnout is the highest in comparison to other branches in Poland. For more than forty years the phenomenon of burnout has been generating a great interest among psychologists and management professionals. The literature concerning this subject delivers many studies and a lot of research concerning the diagnosis of burnout and its predictors, especially among the professionals who are engaged in helping relationships with their patients, clients or pupils. The contemporary theories of burnout define this phenomenon as a "disordered professional relationship" between an individual and his/her job, environment, external expectations etc. (Maslach, Leiter, 2007, 2008, 2010, 2011). What is more, the spectrum of the symptoms of burnout includes the understanding of work disappointment as an existentialaxiological issue that embraces work dissatisfaction, lack of self-realization and failure in meeting one's expectations (Santinello, 2003, 2008, 2014). It is worth emphasizing that the problem of coping with the consequences of long-term occupational stress was brought to attention by a legislative action that had been taken by the European Union. The legal framework for the discussion about workers' health and safety (as well as about the possible prevention measures) was set by Council Directive 89/391/EWG of 12 June 1989 on the introduction of measures to encourage improvements in the safety and health of workers at work (Dz. U. L. 183 of 29 June 1989, hereafter referred to as Framework Directive), with the last modification dating 2008. In the Article 5 (1), the Directive defines a wide scope of employer's responsibility, who is excepted to "ensure the safety and health of workers in every aspect related to their work". Each member state of the European 
Union is responsible for setting its own "basic" framework for actions necessary to reduce psychosocial risk at work. The Belgian legislation remains an undisputed leader in this respect. Due to legal changes, in force from 1 September 2014, not only did it introduce a definition of psychosocial risk to the domestic legal system but also imposed a number of obligations on the Belgian employers which aim to prevent their occurrence.

\section{The Research Material and Analytical Tools Used During the Research}

The research was conducted on June and July 2017 on the group of 153 people working in the following areas: healthcare (mid-level staff, mostly nurses, 64 people), education (teachers, 46 people), higher education (academic teachers, 43 people). Table 1 groups the respondents on the basis of the survey demographic questions.

Table 1: The division of the sample by the characteristics included in the demographic questions

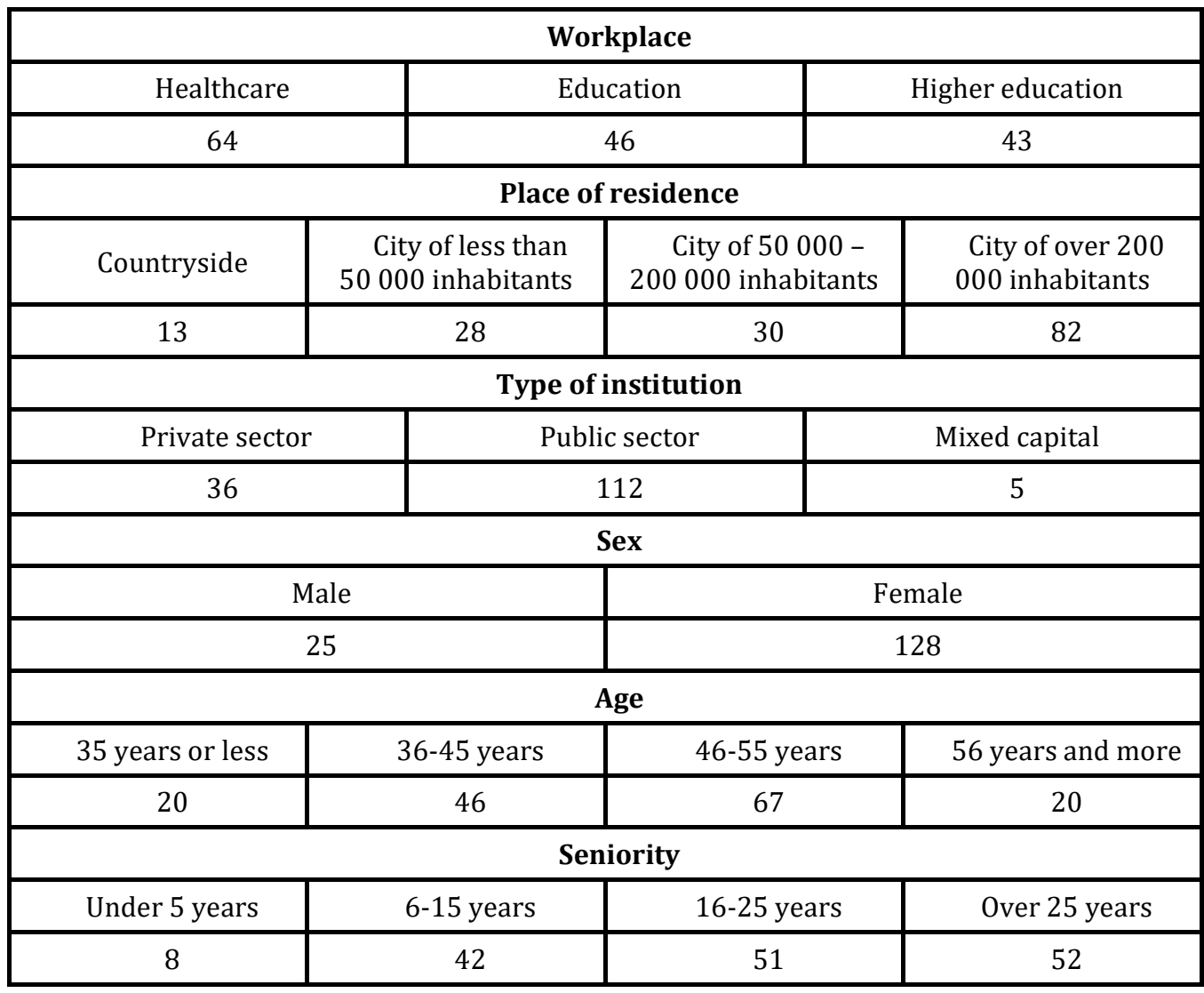

Source: own calculations

Most of the respondents are residents of cities of more than 200000 inhabitants. 112 people work in the public sector, 36 in the private sector and 5 in mixed enterprises. This structure derives from the fact that the considerable number of schools and bigger universities are public institutions. There was a significant prevalence of women over men in the sample (128 versus 25), which clearly reflects the extent to which the teaching and nursing profession are femaledominated. The sample is divided by age as follows: the respondents aged 46-55 (67 people) and those aged 36-45 (46 people) form the most numerous groups; the other two groups, i.e. "35 years and less" and "55 and more" involved 20 participants. 52 respondents have been working in their profession for over 25 years, 51 people 
have gained the seniority of 16 to 25 years, 42 respondents declared 5 to 15 years of professional experience and 8 people have been working in their profession less than 5 years. Most of the respondents - due to the formal requirements in the analysed professions - received higher education (115 people); others got secondary education (that includes 14 people who graduated from Further Education College). It should be underlined that in this presented research authors didn't take into detailed analysis the seniority of researched groups. As it has been presented, most of the researched group are very experienced professionals (about 145 people from the sample). Many research studies (Maslach, Leiter, 2010, 2011, Sęk, 2011) suggest that paradoxically very often younger employees are experiencing higher level of burnout. It is caused by their approach to work; often it's not adequate to the real requirements of the job position. Additionally, they didn't gather as much experience to effectively deal with stress and difficult situations as older employees. Two types of questionnaires were used for the purpose of this research. The first was an LBQ Burnout Questionnaire, which is an adaptation of an Italian Link Burnout Questionnaire (Santinello, 2008, 2014), which enables to measure the level of experienced burnout and which has standardized normalization for Polish population of researched groups (made by Polish Psychological Association). In 2013, a team from the Psychological Test Laboratory of the Polish Psychological Association conducted standardization and validation studies among five professional groups who are engaged in helping other people (teachers, nurses, medical professionals, uniformed services, in total $\mathrm{N}=995$ people with at least one year of seniority, aged 19-65, from all around Poland). The psychometric properties of the questionnaire for the Polish sample were characterised by high reliability. The estimated reliability of the measurement carried out with the use of Cronbach's alpha measure was sufficiently high, which proves the adequacy of the research tool to national conditions. We based the likelihood of our research in the field of a test assessing the level of occupational burnout on the results of reliability assessment conducted by the Polish Psychological Association. The other questionnaire has been originally devised by the authors to assess the perception of the phenomenon among Polish employees. The LBQ questionnaire allows to diagnose four key aspects of burnout, i.e. psychophysical exhaustion, lack of involvement in relationships with clients (patients, pupils, etc.), lack of sense of professional selfefficacy (effectiveness) and career disappointment. The psycho-physical aspect includes the self-assessment of one's own psycho-physical resources like stress level, mental pressure and fatigue. The aspect concerning relationships with recipients raises the issue of the quality of the relationships (with patients, pupils, clients, etc.) and helps to study an individual and subjective attitude towards social environment at work. The aspect of professional effectiveness refers to how an individual assesses his/her professional competence, while the aspect regarding career disappointment concerns the existential expectations that an individual holds for their work, job satisfaction, enthusiasm for work and the sense of professional fulfilment. The tool possesses satisfactory psychometric characteristics. It consists of 24 positions - statements that describe the feelings of a subject towards his/her work. Respondents answer the questions using the six-level frequency scale (the scope of which is: "never", "seldom", "once or a few times per week", "roughly once per week", "a few times per week", "everyday").

The original questionnaire was to assess the extent to which the phenomenon is recognized among the Polish employees. It comprised 26 questions, 22 of which were closed, 4 questions were open and 6 questions were demographic ones. The closed questions were twofold: they either determined the occurrence of a given factor (when a respondent answered one or more questions from the cafeteria) or assessed the level of occurrence of a given factor (on an 11- level scale, from 0 to 10). This measurement wasn't psychometrically tested yet. It's original scale, during the 
statistical description. The collected materials will be used to study the psychometric properties of the obtained results based on the factor analysis and reliability assessment, but this will be the topic of another article. In the presented article, we focus on individual questions and assessment of specific work and life characteristics as predictors of occupational burnout.

The part of the original questionnaire used in the article has been included in the appendix.

\section{The Results of The Research with The Use of LBQ Burnout Questionnaire}

The results of the LBQ survey are presented as sten scale (0-10 scores in psychology diagnosis), which enables faster and more accurate interpretation for psychologists. The LBQ tool diagnoses the level of burnout in reference to three states experienced by subjects: low (1 - 3 scores), average (4 - 7 scores) and high (8 - 10 scores). It enables analyzing four aspects (dimensions) of burnout. If any of the dimensions of the questionnaire receives high scores it means - according to the subject matter - that there is a potential threat of burnout in this particular area. Nevertheless, it is important to stress that even average results are an alarming sign indicating problems with functioning at work. That originates, among others, from the dynamics of the burnout process which is known to intensify with time, together with its symptoms. The process deepens unless there have been some interventions or significant events in an individual's professional or private life (Cherniss, 1992, Golembiewski i in. 1993a, 1993b). The results of the conducted survey with the aid of LBQ questionnaire allow to confirm the hypothesis stating that the phenomenon of burnout is omnipresent among the Polish employees working in healthcare, education and higher education sector. From the perspective of emotional depletion (understood as psycho-physical and emotional fatigue, sense of helplessness, being overwhelmed with work), each of the three groups achieved similar results. In the healthcare sector
$75 \%$ of subjects experience the average level of emotional exhaustion, while only $8 \%$ of them highly developed this symptom. Among the group of teachers, $72 \%$ respondents report being moderately fatigued with their work and 13\% declare that their level of fatigue is high, which suggests a very high level of stress and strain. Among the higher education professionals, $77 \%$ is moderately affected and $14 \%$ is highly affected by exhaustion. Psychological studies confirm that emotional depletion, which is sometimes viewed as a consequence of excessive occupational stress, is the first and the most common symptom of burnout. It is those factors that discriminate between "healthy" occupational functioning and behaviours that are an imminent threat to the well-being of an individual and his/her closest socio-professional environment.

As much as $19 \%$ of academic teachers report that their involvement in occupational relationships is highly disordered, and $72 \%$ of them is declaring the average level of involvement, which is still an alarming figure bearing in mind how dangerous the issue in question is. This means that the professionals dissociate themselves from their working environment, draw away from social relations and let the quality of working relations deteriorate. Furthermore, this area of burnout clearly exposes a cynical and hostile attitude towards service recipients, which leads to difficulties in interaction between a subject and his/her working environment. The findings conclude that academic professionals who are expected to demonstrate professional and educational competences (thus expected to hold high educational standards and share their knowledge with students) are having serious problems with functioning in this area effectively. It is evident that this professional group could suffer from a deficiency in interpersonal skills, which would help them overcome challenging situations involving their students or co-workers. While healthcare workers and teachers attend trainings and seminars quite often, it is not so when it comes to higher education. There is still no qualitative support that would develop 
teaching and mentoring skills, which are essential to succeed as an academic teacher.

An interesting finding emerged while analysing the level of lowered professional self-efficacy, a combination of low selfconfidence and a sense of effectiveness in handling day-to-day working obligations. Only 7\% of the academic teachers report a high level of this indicator of burnout; 19\% of the respondents declared a belief that their level of professional effectiveness is high. By comparison, 11\% of the subjects from the healthcare sector received a high score and $20 \%$ received a low one. In the group of school teachers, $13 \%$ is facing a high sense of ineffectiveness at work, while $24 \%$ reported being satisfied with their effectiveness and performance. One possible explanation is that, although they had been asked to assess their work in general, the surveyed academic teachers concentrated only on the effects of their research work (which seems quite implausible given their range of responsibilities). It may also be that the findings illustrate a narrow perspective of the academic teachers (when it comes to assessing professional effectiveness) and a tendency to overestimate one's results during the interview. The highest score according to the job satisfaction and the least positive results were observed among the higher education professionals. While as much as $93 \%$ of the academics are disenchanted with their work at a moderate level ( $12 \%$ at a high level), the figure is lower among the healthcare workers $(70 \%)$ and the school teachers $(78 \%)$. This dimension of burnout puts emphasis on the negative feelings of subjects, which are closely related to their experiences and existential beliefs. These are aroused when a person experiences a dissonance between the realities of work and aspirations combined with values that simply cannot be satisfied in a particular workplace environment.

By using the results of LBQ Questionnaire, an attempt was made to classify the homogenous groups on the basis of experiencing the phenomenon of burnout in the four analysed areas. In this regard, a two-step cluster analysis was used. TwoStep Cluster Analysis is to be found, among others, in SPSS v. 24.0. On the one hand, it is a method which allows to include categorical and continuous variables; on the other hand, it is proof against not meeting the assumptions of normal distribution and the independence of the input data (Kwiatkowska, Załuska, Dziechciarz 2007, SPSS 1999). After applying a procedure with automatic selection of number of clusters, with a condition concerning changes in the likelihood ratio (BIC change), five groupings were filtered out (see Table 2). In the next sixth step, the change in the likelihood ratio was not significant (BIC change at the level - 15, BIC change ratio below 0,1 ). In the opinion of the authors, a further analysis of the results reveals an interesting classification. The classification is statistically reliable due to the fact that the criteria of cohesion and separation are fulfilled. Figure 1 shows the results of the classification quality assessment. Using the thresholds adopted by the authors of this assessment method, it is assumed that up to 0.2 the classification is poor, from 0.2 to 0.5 it is medium, and above 0.5 - good. For the results presented in this article, one obtained the result of 0.58 , indicating good quality classification.

Table 2: TwoStep Cluster Analysis - an evaluation of the quality of the classification

\begin{tabular}{|c|r|r|r|r|}
\hline $\begin{array}{c}\text { No. of } \\
\text { clusters }\end{array}$ & $\begin{array}{r}\text { Bayesian } \\
\text { information criterion } \\
\text { (BIC) }\end{array}$ & BIC change & $\begin{array}{c}\text { BIC change } \\
\text { ratio }\end{array}$ & $\begin{array}{c}\text { Distance } \\
\text { measure ratio }\end{array}$ \\
\hline $\mathbf{1}$ & 1050,145 & & & \\
\hline $\mathbf{2}$ & 888,587 & $-161,558$ & 1,000 & 1,230 \\
\hline $\mathbf{3}$ & 764,760 & $-123,826$ & 0,766 & 1,195 \\
\hline
\end{tabular}




\begin{tabular}{|l|r|r|r|r|}
\hline $\mathbf{4}$ & 667,672 & $-97,088$ & 0,601 & 1,491 \\
\hline $\mathbf{5}$ & 615,838 & $-51,834$ & 0,321 & 1,637 \\
\hline
\end{tabular}

Source: own calculations

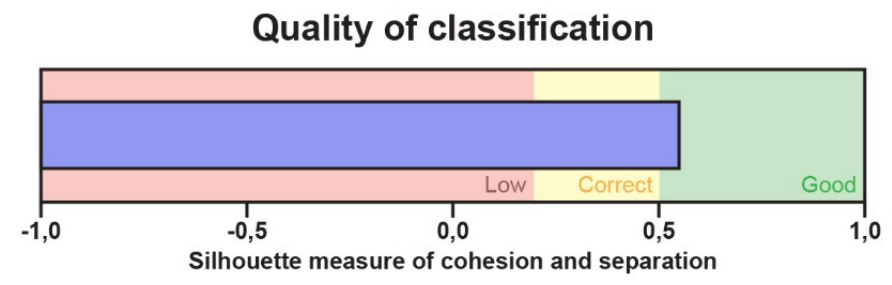

Fig. 1: Two-step Cluster Analysis - an evaluation of the quality of the classification

Source: own calculations

Three clusters out of five turned out to be very cohesive (compare Figure 2): one of the clusters grouped the respondents with high scores in every area and virtually with no low scores (cluster no 1). Another cluster aggregated the respondents with mostly low scores and with no high scores (cluster no 4). There was also a cluster which grouped only the respondents with middle scores on the burnout scale. In order to verify whether there are some differences between the professional groups in terms of burnout, further analysis included the respondents that had been classified to two very contrasting clusters (cluster no. 1 and no. 4). Figure 3 displays the deviations from the expected representation of respondents in particular professional groups. It has been assumed that the expected participation of the respondents in a cluster is proportional to its size and reflects the representation of a given cluster (value $=1$ ). A situation when there are more respondents from a given professional group than expected is called overrepresentation (value $>1$ ). Underrepresentation is the exact opposite of overrepresentation (value $<1$ ).

It is worth noting that there are significant deviations regarding the higher education sector professionals - the overrepresentation in the cluster no. $1(+$ $26 \%$ ) and the underrepresentation in the cluster no. 4 (-35\%).

This means that the representatives of higher education participating in the study are more often exposed to occupational burnout than the representatives of other professions. At the same time, taking into account the results of the answers to the remaining questions, this occupational group find it most difficult to admit that they experience problems causing the risk of burnout and the first symptoms of this phenomenon. According to the authors of the study, this is a clear signal for deepening research in this occupational group in the field of burnout predictors, the possibility of counteracting this adverse phenomenon, as well as the dissemination of the topic of burnout in the group of decision-makers at universities.

At this stage, without conducting any detailed research, only preliminary hypotheses can be made concerning the reasons for such a high risk of burnout in the group of academic teachers. It seems that one of the reasons is the fact that they belong to the group of the so-called highskilled occupations, where one has to perform several different types of activities. In Poland, the vast majority of academic teachers are employed in scientific and didactic positions, which means that they are evaluated for the results of their work in the area of didactics, scientific research and, additionally, organisational and management tasks. D. Prediger, researching various occupations and their specificity, formulated the concept of the World of Work Map $(1993,1999)$. The Map refers to two dimensions of occupational tasks: Data \& Ideas and People \& Things. According to its author, one dimension is 
sufficient for a good description of most occupations, e.g. social occupations (People). However, taking into consideration the assumptions of the Prediger concept and analysing the position of the academic teacher, one can assume that due to the complexity and specificity of the work they perform, this group can fall into the category of Ideas \& Data (scientific activities requiring scientific research, data analysis, interpreting research materials) as well as the category of People, taking into account didactic duties, i.e. work in direct contact with students, mentoring and tutoring, conducting MA, doctoral and diploma seminars, etc. Due to their diversity and level of difficulty, the responsibilities and functions of academic teachers may result in experiencing a kind of "conflict of occupational roles" (Borucki 1988, 1994). According to Z. Borucki's approach, an employee experiences stress when he or she evaluates external requirements as exceeding their capabilities, whereas the environment (work environment) - as insufficient to meet the needs. 


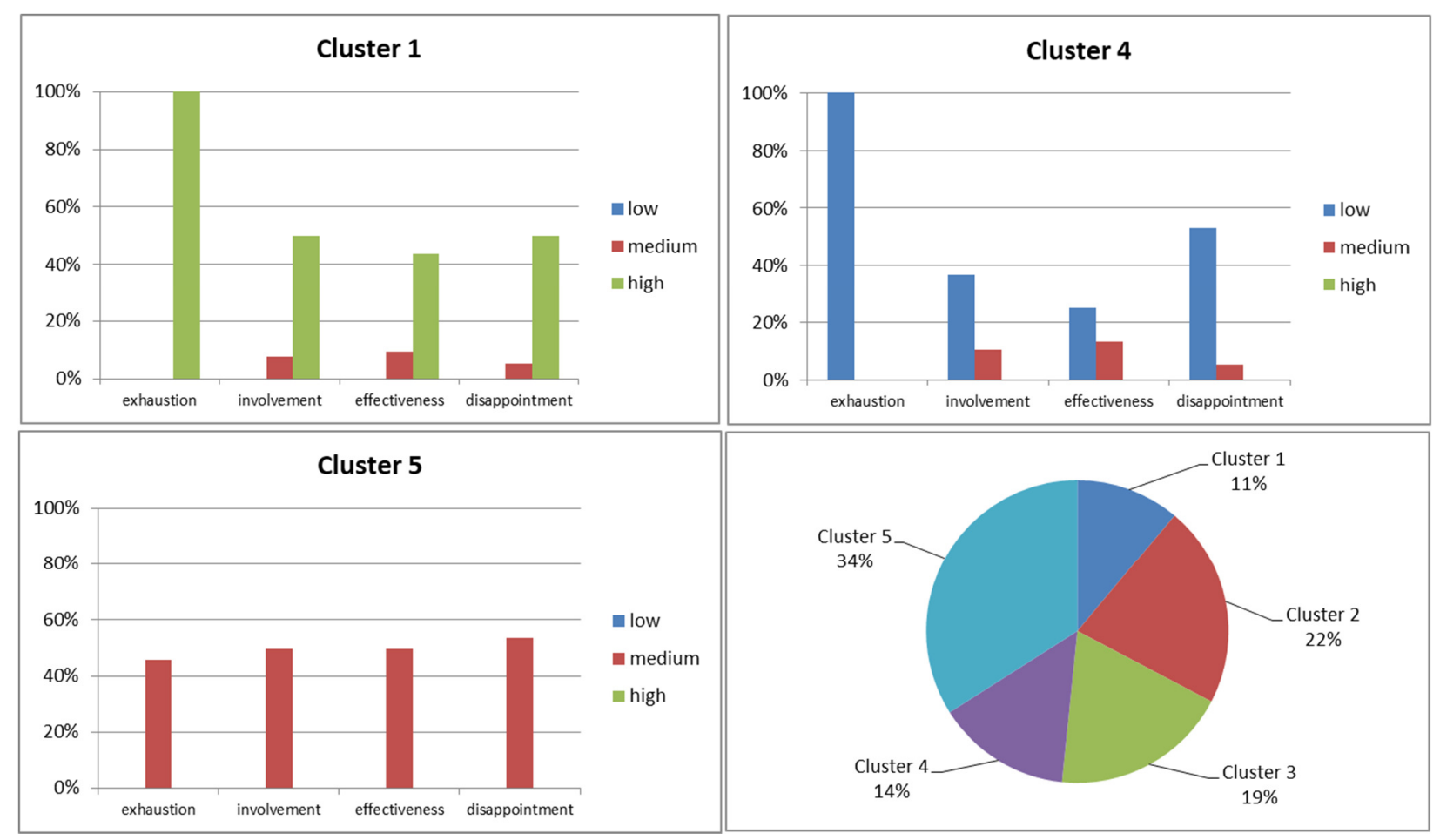

Fig. 2 : Characteristics of the clusters no. 1, 4 and 5 and their volumes

Source: own calculations
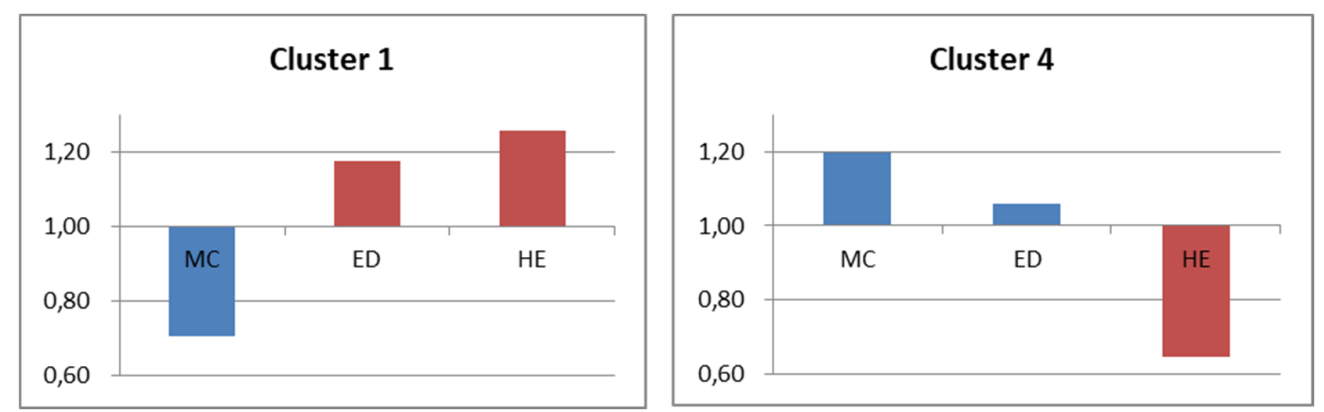

Fig. 3: Overrepresentation / underrepresentation of the professional groups in the cluster no. 1 and 4.

Note: $M C$ - medical care, ED - education, $H E$ - higher education.

Source: own calculations

\section{Main predictors of burnout}

With an aim to identify the key factors that determine the level of burnout in its particular dimensions, a logistic regression was used (SPSS, ver. 24.0). The results of the LBQ that were related to the level of burnout in a given dimension served as dependent variables. The results were aggregated into two categories: 0 - a respondent is characterized by a low level of burnout (scores 1-5), 1 - a respondent is characterized by a high level of burnout (scores 6-10). The set of the potential explanatory variables included two demographic characteristics (namely age and seniority) and the answers to the questions from the original questionnaire (see Table 3). The demographic characteristic „sex” was not included in the analysis given the small number of men among the survey participants. The 
answers to question no. 5 were grouped into two categories: 0 - a respondent never or rarely engages in activities other than professional and domestic responsibilities, 1 - a respondent regularly engages in activities other than professional and domestic responsibilities. In order to find a model that would be significant in terms of F- statistics (the Wald test), the method of stepwise logistic regression was employed. The critical value of the F-statistics was at the significance level $\alpha=0,05$ during forward selection, and $\alpha=0,10$ during backward elimination. To validate the goodness of fit, two tests were used: the Nagelkerke $\mathrm{R}^{2}$ and the Hosmer-Lemeshow test. The latter compares the used model and the null model (with an intercept parameter only) in terms of the relevance of classification (cf. e.g. Gruszczyński, 2002; Heckman, Leamer, 2001).

Table 3: The selected questions of the original questionnaire

\begin{tabular}{|c|l|}
\hline No. & \multicolumn{1}{c|}{ Question } \\
\hline \multicolumn{3}{|c|}{ Type of work } \\
\hline $3 \mathrm{a}$ & High emotional stress \\
\hline $3 \mathrm{~b}$ & Great physical strain \\
\hline $3 \mathrm{c}$ & I am mostly responsible for my work results \\
\hline $3 \mathrm{~d}$ & My work involves contact with others \\
\hline $3 \mathrm{e}$ & A stressful relationship with a supervisor \\
\hline $3 \mathrm{f}$ & Stressful relationships with co-workers \\
\hline $3 \mathrm{~g}$ & Too much bureaucracy \\
\hline $3 \mathrm{~h}$ & A dynamic environment/ a necessity to adapt \\
\hline $3 \mathrm{i}$ & An adequate remuneration for work \\
\hline $3 \mathrm{j}$ & Little success at work \\
\hline $3 \mathrm{k}$ & I feel that my work suits me \\
\hline $3 \mathrm{l}$ & I maintain a work-life balance \\
\hline $3 \mathrm{~m}$ & I am satisfied with my work \\
\hline $3 \mathrm{n}$ & I would like to change my job \\
\hline $3 \mathrm{o}$ & I wish I could take some time off work \\
\hline $3 \mathrm{p}$ & I can influence the way I do my work \\
\hline \multicolumn{3}{|c|}{ Hobby } \\
\hline 5 & Leisure and personal development activities (hobby) \\
\hline $7 \mathrm{a}$ & I have sufficient understanding of burnout \\
\hline
\end{tabular}

Source: own

Figures 4- 7 present the received models for the particular dimensions of burnout and for the professional groups in the form of graphs. The explanatory variables are displayed from top to bottom, in the order they were being added to the model. Under each graph, which represents a combination of a dimension of burnout and a factor (factors) that has (have) influence on it, there are two other parameters. The value of the parameter $B$ is attributed to a given independent variable. The value of the parameter $\exp (B)$ measures how the increase of a predictor by one point will change the probability of transition from category 0 (a low level of burnout) to 1 (a high level of burnout). 


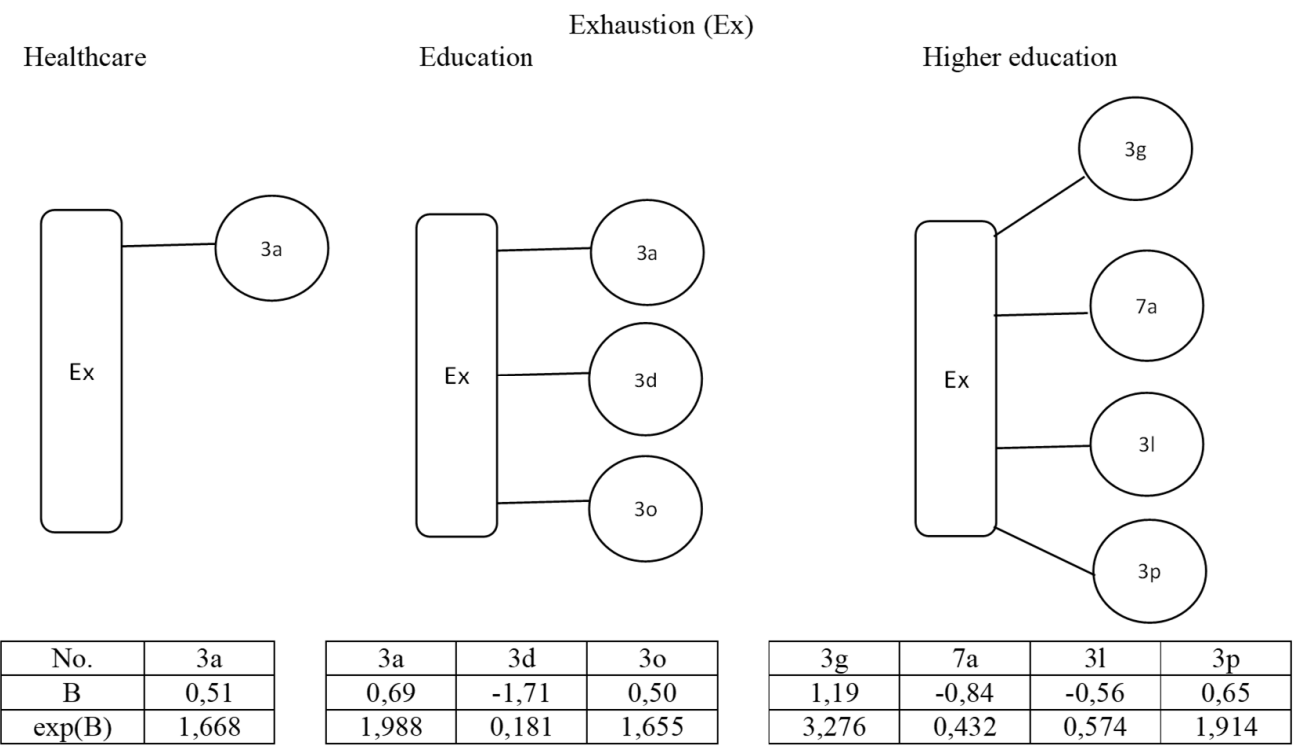

Fig. 4:The factors influencing the level of burnout - exhaustion

Source: own calculations

Healthcare

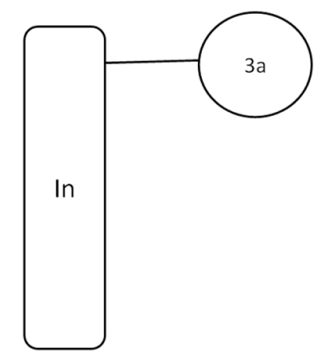

\begin{tabular}{|c|c|}
\hline No. & $3 \mathrm{a}$ \\
\hline $\mathrm{B}$ & 0,23 \\
\hline $\exp (\mathrm{B})$ & 1,262 \\
\hline
\end{tabular}

Involvement (In)

Education
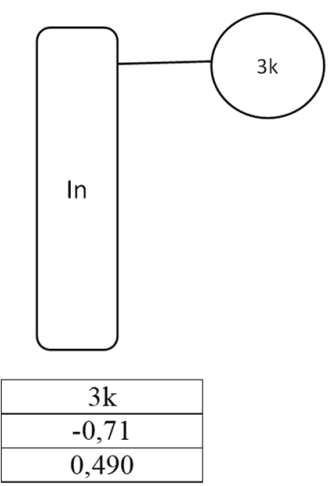

Higher education

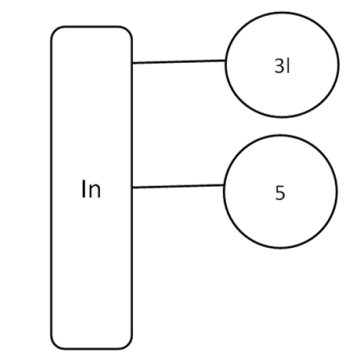

\begin{tabular}{|c|c|}
\hline 31 & 5 \\
\hline$-0,44$ & $-2,20$ \\
\hline 0,646 & 0,111 \\
\hline
\end{tabular}

Fig. 5: The factors influencing the level of burnout - involvement Source: own calculations 
Healthcare

The model's goodness of fit was insufficient
Effectiveness (Ef)

Education

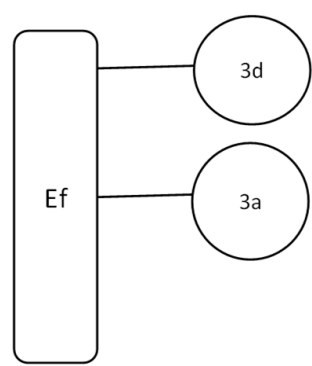

\begin{tabular}{|c|c|c|}
\hline No. & $3 \mathrm{~d}$ & $3 \mathrm{a}$ \\
\hline B & $-1,75$ & 0,55 \\
\hline $\exp (\mathrm{B})$ & 0,173 & 1,736 \\
\hline
\end{tabular}

Higher education

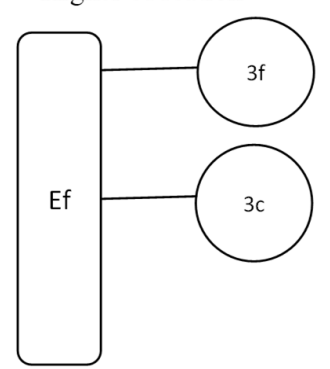

\begin{tabular}{|c|c|}
\hline $3 \mathrm{f}$ & $3 \mathrm{c}$ \\
\hline 0,61 & $-0,38$ \\
\hline 1,843 & 0,685 \\
\hline
\end{tabular}

Fig. 6: The factors influencing the level of burnout - effectiveness

Source: own calculations

Healthcare

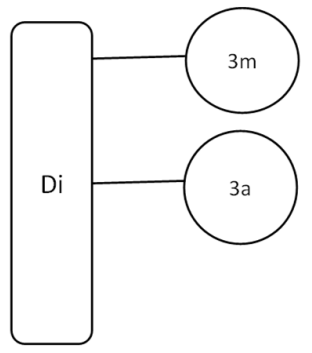

\begin{tabular}{|c|c|c|}
\hline No. & $3 \mathrm{~m}$ & $3 \mathrm{a}$ \\
\hline $\mathrm{B}$ & $-0,350$ & 0,228 \\
\hline $\exp (\mathrm{B})$ & 0,704 & 1,256 \\
\hline
\end{tabular}

Disappointment (Di)

Education

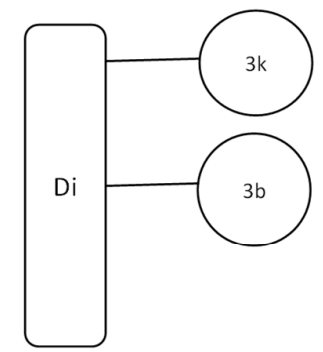

\begin{tabular}{|c|c|}
\hline $3 \mathrm{k}$ & $3 \mathrm{~b}$ \\
\hline$-1,005$ & 0,322 \\
\hline 0,366 & 1,380 \\
\hline
\end{tabular}

Higher education

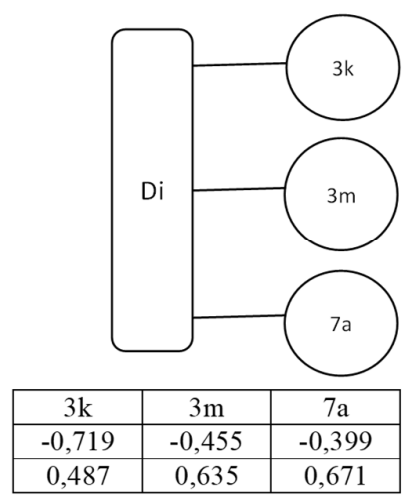

Fig. 7: The factors influencing the level of burnout - disappointment

Source: own calculations

Stress was a factor that played the biggest role as a predictor in the logit models (question no. 3a). It occurred three times in healthcare and two times in education, whereas it did not occur in higher education at all. The model for disappointment in healthcare, apart from revealing a variable referring to high stress, also showed a variable that measures the level of work satisfaction (question no. $3 \mathrm{~m})$. An important factor in education was whether a respondent feels that his/her job suits him (question no. 3k). In higher education the highest importance was attributed to maintaining work-life balance (question no. 3l) and the level of understanding of burnout.

The measured parameters could be interpreted as follows: the dimension of exhaustion, the model for healthcare, question no. $3 a$ : the values of $B=0,512$ and $\exp (B)=1,668$ mean that a growth of the stress level by one measure results in $67 \%$ higher risk of transferring from the category of the low level of burnout to the category of the high level of burnout. The dimension of involvement, the model for 
higher education, question no. 5: the levels of parameter $B=2,199$ and $\exp (B)=0,111$ mean that the probability of experiencing a high level of burnout is lower by $90 \%$ among the people who have got "a regular escape" from the daily work and domestic routine, i.e. hobby.

\section{Results Discussion}

Presented research indicates the universal nature of occupational burnout. This claim is supported by the high LBQ Questionnaire results. Taking into account that in every research group there is a risk of growing burn-out symptoms, potential preventive actions should be seriously undertaken. According to Haemmig (2018) all workloads and job stresses are strongly and positively associated with burnout symptoms and even thoughts of leaving the profession. This broad cross-sectional survey data of 1840 employees working in health care area showed that temporal, physical, emotional and mental workloads and job stresses caused the increasing level of burn out. Based on that research: reducing workload, job stress and minimalizing reward frustration at work, as well as the difficulties in combining work and private lives in this case: health professionals - may help to prevent them from developing burnout or even leaving the profession. According to the suggestion of the authors of a given article, greater attention should be paid to the influence of the work environment factors (workload and work support) to prevent burnout (Yuan, Meng, Kawachi,2019). Considering preventive actions dedicated to professions working with direct contact with others, strategies such as increasing human resources and establishing a supportive work environment are encouraged to prevent and reduce burnout among employees (Al Sabei, Labrague, Miner Ross, Karkada and others, 2020). It is still difficult to convince polish employers to such managerial approach.

Presented research particularly exposed the academic professionals as the group at greater risk of experiencing burnout syndrome in relations to other respondents. Polish academic professionals achieved high scores almost in every component of defining measurement. Based on achieved results: diagnosis of individual competences, motivation to work and level of interpersonal skills, as well as diagnosis of individual coping strategies seems to be particularly important for teachers in general. International research suggest that avoidance coping style predicted higher levels of disengagement, whereas rational coping predicted lower levels of disengagement (Brittle, 2020). It is worth to pinpoint that interpersonal skills of teachers or academic teachers can be significant when it comes to take into account psychological needs of students and pupils. For example: the need of autonomy had a direct effect on academic engagement and academic burnout among students (Ariani, 2019). Teachers' attitude and commitment is therefore crucial for shaping the attitudes and motivation of their mentees.

The results based on logit models clearly indicate the importance of organizational factors in predicting the level of occupational burnout. Not only estimating the level of experienced stress, but also paying more attention to employees' work satisfaction, work life-balance and all psycho-educational activities aimed to deepen awareness of burnout phenomenon: its genesis, symptoms and consequences. Moreover, when it comes to burnout prevention, other regression analyses suggest that specific measures of workload and values could be the strongest predictors of emotional exhaustion and lack of engagement (McCarty, Aldirawi, Dewald, Palacios, 2019), so before taking up any preventive actions, acknowledging organizational conditions and values especially relevant to employees would be strongly recommended.

\section{Concluding Remarks}

The conducted research was of a pilot nature. The conclusions formulated below are a preliminary evaluation of the situation and constitute the basis for further research steps. 
The present research on the phenomenon of burnout that has been simultaneously carried out in healthcare, education and higher education is an attempt to identify similarities and differences between three professional groups. It provides the answers to the initial research questions. The following points can be made:

- The phenomenon of burnout is widely perceived in all of the analysed professional groups.

- The use of logit models worked well to determine the impact of various factors on individual areas of burnout. It should be emphasized that this method gave good effects differentiating the impact of factors depending on the industry and the area of burnout. It turned out that some of the factors are universal and strongly affect most burnout areas regardless of the occupation (e.g. stress), while some are specific to the industry or burnout area (e.g. work-life balance).

- In addition to the predictors listed above, it is worth paying attention to the fact that stress is the main and basically the only factor significantly affecting the level of occupational burnout in health care. In the group of teachers, apart from stress, the sense of being suitable for a given profession and assessment of the need to remain in a professional relationship with other people also play a similar role. In the case of academic teachers, the main predictors of occupational burnout in individual areas are very diverse.

- The outcome of the two-step cluster analysis additionally supports a conclusion that burnout is a common issue among the surveyed professionals and provides justification for deeper exploration of the phenomenon, especially in higher education. Academic professionals experience the typical symptoms of burnout. What is more, the results of the analyses demonstrate that the group is distinctly different from other groups. It achieved high scores in most of the areas (the LBQ Questionnaire).

- Despite the noticeable differences in the perception of burnout among the professional groups subjected to the survey, the adoption of the automatic selection procedure revealed three cohesive clusters that included respondents of diverse occupations. This means that the employees of the analysed professions probably share traits that influence the shape of the process of burnout in a similar way. Undoubtedly, a direct contact with another person is one of those shared traits. Given the aims of the international research project that has been a framework for this paper (building a useful model for the prevention of burnout), what seems to be particularly important is to conduct a longitudinal research that would illustrate the dynamics of the respondents' burnout before and after taking the preventive action.

It should be underlined that despite the great amount of interesting research results, it's not possible to present all findings in this article. The authors decided to concentrate on particular aspects of their project, based on presented research questions. More demographical findings and their connections with burnout syndrome are presented in another publication (Załuska, Ślazyk-Sobol, Kwiatkowska-Ciotucha, 2018).

\section{Acknowledgments}

The project is financed by the Ministry of Science and Higher Education in Poland under the programme "Regional Initiative of Excellence" 2019 - 2022 project number 015/RID/2018/19 total funding amount 10 721 040,00 PLN

\section{References}

- Ajoudani, F., Baghaei, R. and Lotfi, M. (2019), 'Moral distress and burnout in Iranian nurses: The mediating effect of workplace bullying,' Nursing Ethics, 26 (6), 1834-1847.

- Ariani, D W. (2019) 'Basic psychological needs as predictors of burnout and engagement, 'Journal of Psychological and Educational Research, 27 (2), 51-74. 
- Al Sabei, S D., Labrague, L J., Miner Ross, A., Karkada, S., Albashayreh, A., Al Masroori, F. and Al Hashmi, N. (2020), 'Nursing Work Environment, Turnover Intention, Job Burnout, and Quality of Care: The Moderating Role of Job Satisfaction,' Journal of Nursing Scholarship, 52 (1), 95104.

- Bedyńska, S. and Cypryańska, M. (eds.) (2013) Statystyczny Drogowskaz 1. Praktyczne Wprowadzenie do Wnioskowania Statystycznego, Wydawnictwo Akademickie Sedno Sp. z o.o., Warszawa.

- Borucki, Z. (1988) Stres Organizacyjny: Mechanizm, Następstwa, Modyfikatory, Uniwersytet Gdański, Gdańsk.

- Borucki, Z. (1994), Interakcyjna koncepcja stresu organizacyjnego, Psychologiczne wyznaczniki sukcesu w zarządzaniu, Witkowski, S. (ed.), Uniwersytet Wrocławski, Wrocław.

- Brittle, B. (2020), 'Coping strategies and burnout in staff working with students with special educational needs and disabilities,' Teaching and Teacher Education, 87.

- Cherniss, C. (1980) Staff Burnout. Job Stress in the Human Services, Sage Publications, Beverly Hills.

- Cherniss, C., (1992), "Long - term consequences of burnout. An exploratory study.'Journal of Organizational Behavior. [Online], [Retrieved January 7, 2020], http://dx.doi.org/10.1002/job 13, 1-11.

- Cherniss, C. (1995) Beyond Burnout: Helping Teachers, Nurses, Therapists and Lawyers Recover from Stress and Disillusionment, Routledge, New York. https://doi.org/10.4324/9781315021904

- Cieślik, K., (2012), "Zorientowani na działanie odporni w pracy,' SWPS Uniwersytet Humanistycznospołeczny. [Online], [Retrieved December 29, 2015], http://www.swps.pl/wroclaw/wroclawaktualnosci/wroclaw-doniesienia-zeswiata-nauki/9415-zorientowani-nadzialanie-odporni-w-pracy.

- Dyrbye, LN., West, CP., Johnson, PO., Cipriano, PF., Beatty, DE., Peterson, C., Major-Elechi, B. and Shanafelt, TD. (2019), 'Burnout and Satisfaction with Work-Life Integration among Nurses,' Journal of Occupational and Environmental Medicine, 61 (8), 689-698.
- Gavish, B and Friedman, I A. (2010), 'Novice Teachers' Experience of Teaching: A Dynamic Aspect of Burnout,' Social Psychology of Education: An International Journal 13 (2), 141-167.

https://doi.org/10.1007/s11218-009-

9108-0

- Golembiewski, R T.(1993a), Burnout in cross - national sttings. Generic and model - specific perspectives, Proffessional Burnout: Recent Developments in Theory and Research, Schaufeli, W B., Maslach, C., Marek, T. (ed.), Tylor \& Francis, Scherb K, \& Boudreau R.A., Washington. (pp. 217 - 236) - Golembiewski, RT., Boudreau, RA., Goto, K. and Murai, T. (1993b), 'Transnational perspectives on job burnout: replication of phase model results among Japanese respondents,' The International Journal of Organizational Analysis, 1 (1), 7-27

- Gruszczyński, M. (2002) Modele i Prognozy Zmiennych Jakościowych w Finansach i Bankowości, Wydawnictwo SGH, Warszawa.

- Heckman, J. and Leamer, E. (2001) Handbook of Econometrics, Elsevier, Amsterdam.

- Hämmig, 0. (2018) 'Explaining burnout and the intention to leave the profession among health professionals - A crosssectional study in a hospital setting in Switzerland,' BMC Health Services Research, 18 (1).

- Kwiatkowska-Ciotucha, D., Załuska, U. and Dziechciarz, J. (2007) Analiza Porównawcza Odczuć Satysfakcji Zawodowej - Polska na Tle Wybranych Krajów Unii Europejskiej, Wydawnictwo Akademii Ekonomicznej we Wrocławiu, Wrocław.

- Lubrańska, A. (2012) 'Środowisko Pracy a Wypalenie Zawodowe - Analiza Wzajemnych Relacji na Przykładzie Badań Reprezentantów Różnych Obszarów Aktywności,' Acta Universitatis Lodziensis. Folia Psychologica, 16, 35-45.

- McCarty, WP., Aldirawi, H., Dewald, S. and Palacios, M. (2019), 'Burnout in Blue: An Analysis of the Extent and Primary Predictors of Burnout Among Law Enforcement Officers in the United States,' Police Quarterly, 22 (3), 278-304.

- Majchrzak, I. (2011) 'Wypalenie Zawodowe u Nauczycieli Akademickich,' Folia Pomeranae Universitatis 
Technologiae Stetinensis, Oeconomica, 287 (63), 137-146.

- Maslach, Ch. and Jackson, S. (1981), 'The measurement of experienced burnout,' Journal of occupational behaviour, 2, 99113, https://doi.org/10.1002/job.4030020205 . - Maslach, Ch., Jackson, S E. and Leiter M P. (1996) MBI Manual. 3rd ed. Mountain View, CPP Inc, CA.

- Maslach, Ch. (1998) A Multidimensional Theory of Burnout, Theories of organizational stress, C.L. (ed), Oxford University Press, New York. (pp. 68 - 85)

- Maslach, Ch. and Leiter, M P. (2007), Burnout, Encyclopedia of Stress, Fink, G. (ed), Elsevier, New York. (pp. 368-371)

- Maslach, Ch and Leiter, M P. (2008), 'Early predictors of Job burnout and engagement,' Journal of applied psychology 93 (3), 498-512.

- Maslach, Ch. and Leiter, M P. (2010) Pokonać Wypalenie Zawodowe. Sześć Strategii Poprawiania Relacji z Pracą, Oficyna Wolters Kluwer Business, Warszawa.

- Maslach, Ch. and Leiter, M P. (2011) Prawda o Wypaleniu Zawodowym. Co Robić ze Stresem w Organizacji, Wydawnictwo Naukowe PWN, Warszawa.

- Prediger, D., Swaney, K. and Mau, W. (1993), 'Extending Hollandís hexagon: Procedures, counseling applications and research,' Journal of Counseling and Development 71, 422-428., https://doi.org/10.1002/j.1556-

6676.1993.tb02659.x

- Prediger, D. (1999) 'Basic structure of work-relevant abilities,' Journal of Counseling Psychology, 42, 178-184.

- Ruggieri, RA., Crescenzo, P., Iervolino, A., Mossi, P.G. and Boccia, G. (2018),
'Predictability of big five traits in high schooteacher burnout. Detailed study through the disillusionment dimension,' Epidemiology Biostatistics and Public Health, 15 (3).

- Santinello, M., Dallago, L., Dal Ponte, A. and Fontana, F. (2003), 'Gestire lo stress nelle organizzazioni: L'esperienza dell'Azienda sanitaria provinciale trentina,' Tendenze Nuove, 1, 45-66.

- Santinello M. (2008) LBQ Link Burnout Questionnaire. Manuale, Giunti O.S. Organizzazioni Speciali, Firenze.

- Santinello, M. (2014) LBQ Kwestionariusz Wypalenia Zawodowego. Podręcznik, Pracownia Testów Psychologicznych Polskiego Towarzystwa Psychologicznego, Warszawa.

- Sęk, H. (ed.). (2011) Wypalenie Zawodowe. Przyczyny i Zapobieganie, PWN, Warszawa.

(1999), SPSS Advanced Models, SPSS Incorporation, Chicago.

- Świętochowski, W. (2011), 'Wypalenie zawodowe nauczycieli akademickich i nauczycieli szkoły średniej - analiza porównawcza,' Medycyna Pracy, 62 (2), 133-143.

- Załuska, U., Ślazyk-Sobol, M. and Kwiatkowska-Ciotucha, D. (2018) Burnout and its Correlates - an Empirical Study Conducted among Education, Higher Education and Health Care Professionals, Econometrics. Advances in Applied Data Analysis, $22 \quad$ (1), 26-38. https://doi.org/10.15611/eada.2018.1.02.

- Li, H., Yuan, B., Meng, Q. and Kawachi, I. (2019), 'Contextual factors associated with burnout among Chinese primary care providers: A multilevel analysis,' International Journal of Environmental Research and Public Health, 16 (19). 


\section{Appendix. Selected questions from the original survey questionnaire.}

\begin{tabular}{|c|c|c|}
\hline 3 & $\begin{array}{l}\text { Firstly, let us ask you some general } \\
\text { questions about your work. Please assess } \\
\text { to what extent each of the questions } \\
\text { describes your current job. } \\
\text { Use the scale of } 0 \text { to } 10 \text {, where } 0 \text { - } \\
\text { definitely inadequate, while } 10 \text { - definitely } \\
\text { adequate. }\end{array}$ & $\begin{array}{ll}\text { a. } & \text { High emotional stress } \\
\text { b. } & \text { Great physical strain } \\
\text { c. } & \text { I am mostly responsible for my work results } \\
\text { d. } & \text { My work involves contact with others } \\
\text { e. } & \text { A stressful relationship with a supervisor } \\
\text { f. } & \text { Stressful relationships with co-workers } \\
\text { g. } & \text { Too much bureaucracy } \\
\text { h. } & \text { A dynamic environment/ a necessity to adapt } \\
\text { i. } & \text { An adequate remuneration for work } \\
\text { j. } & \text { Little success at work } \\
\text { k. } & \text { I feel that my work suits me } \\
\text { l. } & \text { I maintain a work-life balance } \\
\text { m. } & \text { I am satisfied with my work } \\
\text { n. } & \text { I would like to change my job } \\
\text { o. } & \text { I wish I could take some time off work } \\
\text { a } & \text { (e.g. way of working, selecting tasks) } \\
\end{array}$ \\
\hline 5 & $\begin{array}{l}\text { Do you take part in any leisure or } \\
\text { personal development activities, other } \\
\text { than your professional and domestic } \\
\text { duties? }\end{array}$ & $\begin{array}{l}\text { Yes, regularly } \\
\text { Yes, although sporadically } \\
\text { No }\end{array}$ \\
\hline \multirow[t]{2}{*}{7} & \multicolumn{2}{|c|}{$\begin{array}{l}\text { Please think about „burnout” for a moment. How would you describe your level of understanding } \\
\text { of this phenomenon? Please describe to what extent you agree with the following statements using } \\
\text { a scale of } 0 \text { - I completely disagree to } 10 \text { - I completely agree. }\end{array}$} \\
\hline & $\begin{array}{l}\text { a. I have sufficient understanding of burno } \\
\text { b. I could recognize the symptoms of burno } \\
\text { c. I am able to tell whether somebody else }\end{array}$ & It if they affect me personally \\
\hline
\end{tabular}

